\title{
Elementary School Teachers and Sex Education in Mexico: The Case of Veracruz
}

\author{
Ana Lis Heredia Espinosa,a, Adriana Rodríguez Barraza ${ }^{b}$
}

\author{
Received \\ Revised \\ Accepted \\ $\mathrm{DOI}$
}

\author{
12 February 2021 \\ 13 May 2021 \\ 5 June 2021 \\ 10.26822/iejee.2021.214
}

"a Corresponding Author: Ana Lis Heredia Espinosa, Institute of Psychological Research Universidad Veracruzana, Xalapa, Veracruz, Mexico.

E-mail: aheredia@uv.mx

ORCID: http://orcid.org/0000-0002-3998-3003

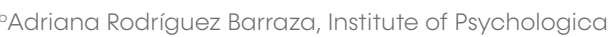
Research Universidad Veracruzana, Mexico.

E-mail: adrirodriguez@uv.mx

ORCID: http://orcid.org/0000-0003-4833-9540

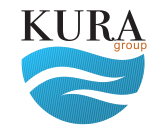

Copyright @

www.iejee.com

ISSN: 1307-9298

(C) 2021 Published by KURA Education \& Publishing. This is an open access article under the CC BYNC- ND license. (https://creativecommons.org/ licenses/by/4.0/)

\begin{abstract}
Elementary school teaches children to read and write, develop math skills, live together, explore the world, understand that world at a basic level, and grow as people. The objectives of this article are to examine the beliefs of elementary school teachers regarding sex education, to gain a notion of the limits and scope of sex pedagogy in the approach to content, and to provide accurate information for decision-making and public policy. A descriptive study was conducted using a qualitative methodology. The data were collected between October and December 2019 in two public elementary schools in the City of Veracruz, State of Veracruz, Mexico. A non-probabilistic sampling method with a maximum variation was used in the study. In total, nine teachers of ages ranging from 22 to 64 years participated. The teachers reported that the students must have reached sexual maturity to talk about sexuality. Likewise, a discourse that emphasizes the biological aspects and the belief that abstinence is the best way to prevent unwanted pregnancy predominates. Finally, there were different opinions regarding the need for training teachers to teach sex education.
\end{abstract}

\section{Keywords:}

Beliefs, Elementary School, Sex Education, Teachers

\section{Introduction}

Primary Education

Primary education in Mexico is constitutionally compulsory, must be accessible, and by mandate is secular. According to the type of support, public schools can get either federal or state aid. Federal elementary schools are subsidized by the national government and administered by the Ministry of Public Education (known as the SEP in Mexico). In contrast, state elementary schools are subsidized by the Secretary of Education in each state.

There is a vast disparity in the number of men and women in the teaching profession. According to the National Institute of Statistics, Geography, and Informatics in Mexico (INEGI, 


\section{iejee}

2020), at the primary level, most teachers are women: in preschool, the difference is drastic given that $94 \%$ are women and $6 \%$ are men; in elementary school, $67 \%$ of teachers are women and $33 \%$ are men; and in secondary school, $57 \%$ are women and $43 \%$ are men. Wood (2012) examined teacher perceptions of gender-based differences among elementary school teachers in the USA. She found that more than half of the participants believed that female teachers are more nurturing, and that male teachers are more commanding with students. We must also consider the organization in preschool and elementary school where a teacher is responsible for teaching all subjects to the group. From secondary school, given the breadth of subjects taught, there is a teacher for each type of academic course.

\section{Preparation of Primary School Teachers}

In Mexico, most of the primary-level teachers (preschool, elementary, and secondary) are trained in the so-called Normal Schools. The Normal Schools are educational centers dedicated specifically and exclusively to training teachers. The term "Normal" is related to the idea that these establishments should serve as a norm or model for the others in their class (Meneses, 1999).

The training approaches that circulate in this institution parallel the national educational policies, while the Mexican government, through the Ministry of Public Education (SEP), dictates the guidelines for the training of future teachers (Navarrete, 2015).

The Normal Schools educate the teachers responsible for shaping future citizens. The direct antecedent of creating these schools was the pedagogical model of Enrique Rébsamen, first applied in Veracruz. Rébsamen was a Swiss pedagogue who arrived in Mexico in 1883. In 1885, Governor Juan de la Luz Enríquez entrusted him with a short course for the education of teachers in the region. Enrique Laubscher was another European pedagogue; he was of German origin and he promoted the founding of the first Normal Schools, where the pedagogical doctrine and the scientific bases would regulate educational development, mainly in public schools. At the end of the 19th century and the beginning of the 20th century, primary education was considered essential to achieving the ideal consolidation of national unity.

The Normal Schools in Mexico today are part of a diverse set of establishments dedicated to teachers' preparation. Throughout history, they have been reducing their number in terms of school enrollment and budget. According to their educational level, Normal Schools are divided into preschool, elementary, and secondary. There are two other types of schools that prepare specialized teachers, one for children with disabilities, and another for physical education. Currently, future elementary school teachers trained in the Normal Schools study a series of subjects that mainly fall into three categories:

1) Theoretical-methodological bases for teaching, including pedagogical models, planning, evaluation, and legal and normative bases of primary education.

2) Training for teaching and learning, which includes three areas: (1) the development of reading skills, the production of written texts, literature, theater, language, and communication; (2) algebra, geometry, statistics, music, and physical education; and (3) the natural sciences, environment, geography, history, civics, and ethics.

3) Professional practice, which includes observing and analyzing educational training, teaching work strategies, and school improvement projects.

\section{Elementary School Curriculum}

Elementary school lasts for six years and provides basic knowledge of Spanish, mathematics, and the sciences, and it is held in the morning (8:00 a.m. to 12:30 p.m.) or the afternoon (2:00 p.m. to 6:30 p.m.).

The school curriculum is the instrument that can structure schooling, the operation of educational centers, and pedagogical practices since it provides, transmits, and imposes rules, norms, and a determining order for the way that students should work in classes (Gimeno, 2010). In other words, it is the backbone of teaching in the classroom.

The SEP determines the curriculum. All the country's elementary schools base their curriculum on the SEP through textbooks that have been distributed free of charge since 1959. Palencia and González (2015) point out the importance of school textbooks in the general population's education since, for the majority, they could be the only books they will read in their lives. It is worth mentioning that the contents are determined by the state following the educational policies of the moment. Speaking about sexuality issues, they have been in the natural science textbook since 1974.

\section{Sex Education Curriculum}

In Mexico, the selection of content on sexuality uses the definitions given by the World Health Organization (WHO) as guidelines. According to the $\mathrm{WHO}$, sex 
education aims to develop and strengthen children and young people's ability to make conscious, satisfying, healthy, and respectful choices regarding relationships, sexuality, and emotional and physical health. Sex education does not encourage children and young people to have sex.

Also, the WHO (2006) defines "sexuality" as a central aspect of being human throughout life that encompasses sex, gender identities and roles, sexual orientation, eroticism, pleasure, intimacy, and reproduction. Sexuality is experienced and expressed in thoughts, fantasies, desires, beliefs, attitudes, values, behaviors, practices, roles, and relationships. While sexuality can include all these dimensions, not all of them are always experienced or expressed. Sexuality is influenced by biological, psychological, social, economic, political, cultural, legal, historical, religious, and spiritual factors

In this regard, Rangel (2018) claimed that in Mexico, discourses on sexuality in elementary schools are established in the curricular guidelines; however, teachers transfer them and reproduce them in interaction with the students. In this sense, it is interesting to cite a study conducted by Mar (2009) with Mexican children in the fifth and sixth grade; the author mentioned that the metaphors that children use to describe the human body depend on what they learn in school. Most children identify the body as a machine or an apparatus; this has to do with the predominance of biomedical discourse and anatomical view of sexuality in the curriculum. In addition, teachers speak of an ethic of sexuality based on a religious nature's conservative morality (Rangel, 2018). Likewise, other studies have addressed Mexico's issue from the testimony of fifth- and sixthgrade elementary school teachers about the contents of books and professional training on sexuality and gender in the Yucatán and in Quintana Roo (Rosales \& Salinas, 2017). However, there are no investigations of this nature in Veracruz.

The preceding allows us to understand the current panorama regarding sexuality in educational centers, which is important because, due to their deficiencies, young people lack a solid base to face situations such as those mentioned below.

\section{Social Problems Associated with the Lack of Sex Education}

Some current social conditions make it necessary to investigate what happens in sex education classes. For example, $23 \%$ of adolescents start their sexual lives between the ages of 12 and 19. Likewise, according to data from the Organization for Economic Cooperation and Development, Mexico ranks first in cases of adolescent pregnancy internationally (OCDE, 2018). Also, figures from the National Institute of Statistics, Geography, and Informatics (INEGI, 2020), revealed that $16 \%$ of the births registered at the national level corresponded to adolescents between 15 and 19 years old. Along the same lines, according to official data published in the National Strategy for preventing pregnancy in adolescents in Mexico 2018 (INMUJERES, 2018), recently, pregnancies have been registered in girls between 10 and 14 years old.

For its part, the state of Veracruz, where this study was carried out, ranks second nationally in adolescent pregnancy, with more than 20,000 pregnancies per year (GIPEA, 2018), and each year that figure increases. Another alarming fact is about maternal mortality. According to the National Council of Medical Arbitration, in terms of maternal deaths in adolescents that occurred in the country from 2002 to 2017, Veracruz ranked third in the country, with a record of 200 deaths in children under 19 years of age (Sánchez \& Montoya, 2019). Likewise, in 2019 Veracruz ranked first in the nation in AIDS infections, with a total of 119 new cases registered, according to data from the National Center for the Prevention and Control of HIV and AIDS.

Thus, we can note that the incorporation of sex education in elementary school will not solve the problems since at a structural, cultural, and personal level, multiple factors have influence, including beliefs. Hence, the importance of doing studies like this one to examine the tremendous impact they have on observing, studying, and teaching students.

\section{Beliefs}

In this sense, beliefs have been studied from various fields. For example, for the philosopher Ortega $y$ Gasset (2000), beliefs shape people's lives because they are put ahead of their perceived reality. There is usually no express awareness of them, but they act latently. When someone truly believes in something, they do not need to be clear about it; their notions are simply incorporated.

Also, for psychologists Martin Fishbein and lcek Ajzen (1975), beliefs are subjective probability judgments of a person regarding some area of their world; they deal with the understanding that subjects have of themselves and their environment. Along the same lines, Díez (2016) declares that belief is a psychological notion that implies the tendency to act as if one's beliefs are true. That means it is a conviction, or something that people consider true.

Therefore, as mentioned, this article's objective is to determine the beliefs of primary school teachers 


\section{iejee $\approx$}

regarding sex education, to determine its limits and scope in the approach of the contents, and to gain information that may be useful for decision-making and public policy. Sex education is a complex issue around which various beliefs are part of widespread knowledge (Ramírez, 2013). These have such a vital value range that they constitute an ethic that justifies and issues value judgments. Likewise, they play a crucial role in configuring daily practices such as gender relations and violence and inequality (Ramírez et al., 2009).

Given Mexico and Veracruz's circumstances, this text is relevant because it addresses the challenges elementary school teachers have regarding sex education and how pedagogy is permeated by what they believe. We think it can provide data that help identify and analyze beliefs since teachers are an agent that can contribute to social transformation, well-being, and people's quality of life.

\section{Method}

This study is descriptive, with qualitative methodology and a comprehensive-interpretive approach. We used the qualitative research interview technique, which allows us to build knowledge through a conversation that has a structure and a specific purpose (Kvale, 2008). Therefore, we conducted semi-structured interviews to determine teachers' perspectives and obtain descriptions of their beliefs and experiences in the approach to sex education. According to Bernard (1995), this method consists of a guide used when there is only one occasion to interview someone. In this case, the teachers had limited time to answer the interview questions because they were at work.

\section{Context}

In Mexico, primary education comprises the first three school levels in the lives of the students:

1. Preschool consists of three grades, and the children attend when they are 3 to 6 years old.

2. Elementary school has six grades, and children enter at the age of 6 and remain until 12.

3. Secondary school has three grades and is generally attended between the ages of 12 and 15 years.

Table 1

Scope of the Questions in the Data Collection Tool

\begin{tabular}{ll}
\hline Research objective & \multicolumn{1}{c}{ Interview guide } \\
\hline & 1. Could you tell me in which subjects sex education contents are covered? \\
& 2. What can you tell me about the content on sex education in the " natural sciences " textbook? \\
To examine teachers' beliefs & 3. How do you think sex education should be done in the grade you teach? \\
regarding sex education in & 4. In what ways have you addressed sexuality in your classes? \\
elementary school & 5. How has your experience been in dealing with sexuality issues with students? \\
& 6. How do you feel about the knowledge of sexuality topics in the curriculum? \\
& 7. Have you completed courses on sexuality? \\
& 8. Do you think teachers should receive training on sex education pedagogy?
\end{tabular}

The State of Veracruz has 212 municipalities. We conducted this study in the City of Veracruz, which has problems including pregnancies in girls and adolescents, maternal deaths, and the profusion of sexually transmitted diseases. Research of this nature is pertinent. The data were collected in two of the largest elementary schools, with the highest number of students and teachers in Veracruz, from October to December 2019. As mentioned above, $67 \%$ of elementary school teachers in Mexico are women and $33 \%$ are men; however, in the two schools where we conducted the research, the teaching staff consisted only of women.

\section{Participants}

We used a non-probabilistic sampling method with a maximum variation (Hudelson, 1994), which means documenting unique or diverse variations over a wide range of ages and years of teaching experience. In total, nine teachers whose ages ranged from 22 to 64 years participated. All are graduates of the Bachelor of Primary Education in Normal Schools, and all are Catholic. Seven of them are married and the other two are single. Three teach fourth grade (children of 9 and 10 years), three fifth grade (children of 10 and 11 years), and three sixth grade (children of 11 and 12 years). Four of them work in a state elementary school, and five in a federal elementary school. We should note that during the interviews, we asked the teachers if at some point in their academic career they had received sex education, to which they all answered in the negative, agreeing with the statement above.

\section{Procedure}

Before proceeding to the fieldwork, the Ethics Committee at the Institute of Psychological Research of Universidad Veracruzana approved the research. The provisions of the Federal Data Protection Law were always complied with. We developed a semistructured interview script based on the research objectives, which aim to examine teachers' beliefs regarding sex education in elementary school and have a notion of its limits and scope in the approach of the contents.

Before beginning each consultation, teachers read an informed consent letter. Each participant was asked to sign it, reiterating that we would record the audio 
but that it would be assigned a pseudonym not to be identified, guaranteeing people's and institutions' confidentiality. On average, the interviews lasted 40 minutes. Interviews were held in various schools' spaces: some in the classrooms and others in the courtyard. We transcribed the interviews verbatim, and we safeguarded the transcripts. We collected around 90 pages of data.

Once we finished the interviews, they were analyzed based on the guidelines established by Kvale (2008) that consist of transcribing, coding, condensing, and interpreting the information obtained until we achieved a definitive categorization. An analysis was performed by the two researchers.

First, we proceeded to encode by hand, that is, to assign keywords to a text segment to allow later identification. Hence, we clustered these codes into mutually exclusive categories. Categorization implies a broader and more systematic conceptualization (Kvale, 2008). Therefore, we reduced the grouped codes to only three categories, with two subcategories in each.

\section{Table 2}

\begin{tabular}{ll} 
Categorization & \\
\hline Category & Subcategories \\
\hline Beliefs about a textbook & $\begin{array}{l}\text { Relevance of the contents. } \\
\text { Omitting content }\end{array}$ \\
$\begin{array}{ll}\text { Beliefs about the characteris- } \\
\text { tics of students }\end{array}$ & $\begin{array}{l}\text { Maturation } \\
\text { Discipline }\end{array}$ \\
Beliefs about teacher training & $\begin{array}{l}\text { Need for teacher training } \\
\text { Indifference toward training }\end{array}$ \\
\hline
\end{tabular}

For the study to be valid, we did a triangulation of evaluators, an intersubjective verification through the contrast of the information we obtained (Denzin, 1979). Likewise, for the study to have internal reliability, we created descriptive categories with a low level of interference, making them as concrete and precise as possible (Le Compte \& Goetz, 1982). In addition, data were collected by two researchers to guarantee a better balance of observations, analysis, and interpretation.

\section{Findings}

Once the transcripts of the interviews were analyzed, we identified three major categories that encompass the beliefs: the contents of the textbooks, the students' characteristics, and teacher training. From these categories, six subcategories emerge that we will explain below.

\section{Beliefs about Textbook Content}

This category includes the beliefs that primary school teachers have about the knowledge, skills, attitudes, and values proposed in the curriculum that teachers will transmit in an educational project (SEP, 2017). Two subcategories emerged. The first is called relevance of the contents, and it refers to beliefs about the importance of sex education content that teachers will transmit during the course. Some teachers do not agree with the curriculum because they believe that students are given too much information. In contrast, others believe that it is important to talk about sexuality because knowledge can prevent abuse.

The second subcategory is called omitting content, and it refers to the belief that it is preferable to avoid addressing issues because they are considered inconvenient for children.

\section{Beliefs About the Characteristics of Students}

Through the analysis of interviews, we discovered that several teachers affirm that, to talk about sexuality with students, specific conditions regarding both maturation and discipline must be present in the group. Therefore, the first subcategory, maturity, refers to the belief that the development of sexual characteristics in students should be taken as a criterion to decide whether to talk about sexuality. One of the requirements is that the girls have already begun menstruating. The second subcategory is discipline; that is, the teachers have the belief that to talk about sexuality with their students, the group must behave appropriately without making jokes; otherwise, the topic is not taught.

\section{Beliefs about Teacher Training}

This last category encompasses beliefs about preparation for teaching, which includes the development of knowledge related to the contents of sexuality and gender and the knowledge and skills required in these subjects. The first subcategory refers to the need for teacher training. This implies a belief in one's lack of updating information on sexuality and gender and improving classroom practice. The last subcategory is Indifference toward training, which refers to the belief that training and updating information on sexuality and gender are irrelevant. Therefore, each teacher can prepare on their own.

\section{Discussion}

Regarding the relevance of textbook contents, we found that teachers avoid topics like sexual relations and contraceptive methods, despite those subjects being marked in the official curriculum. The teachers believe that students are not yet ready to start their sexual lives, as seen in the following speech by a teacher: 
What I have avoided, and that comes in sixth grade books, is that they mention contraceptives... I have not seen that with kids; I do not think it is convenient for the student to know, despite knowing the different types of contraceptives, which are seen not only in elementary school but also in secondary school. I have always used the guideline that the greatest contraceptive is to abstain because they are not yet ready to initiate sexual relations (Samantha).

Iyer and Aggleton's research (2013) in Uganda found that some teachers focus exclusively on abstinence as a preventive method when they talk about sexual matters. Also, a Brazilian study by Da Silva (2012) showed that when students ask about sexuality issues, teachers tend to avoid giving any explanation. In addition, Marseille et al. (2018) and Mirzazadeh et al. (2018) analyzed the effectiveness of school-based teen pregnancy and sexually transmitted infection prevention programs in North America. The results of the studies question the usefulness of interventions carried out in schools to prevent unwanted pregnancies and the incidence of HIV and other sexually transmitted infections in adolescents in North America.

According to Preston (2013), teachers continue to perceive their responsibility as combating sexual risk while viewing young people as immature, even as adolescents express a preference for sex education with less emphasis on strictly adverse sexual outcomes and more focus on peer education. In this sense, another relevant finding is that teachers take the sexual maturity of students as a criterion to decide whether to delve into sexuality issues:

From the fifth grade, I see when we are going to deal with this issue if there are kids who pay attention, and I begin to ask girls if they are already menstruating. I say, "Menstruation... do you know what that is?", and there are girls who say yes, others no. I do a survey, and if I see that the girls still do not understand it well, I treat the topic in general. I talk to the mothers and ask them to explain them too before I start to address them more in-depth. I give my students the example of girls I know from a community where I taught classes who are already pregnant, and I tell them,

\section{Table 3}

Category 1: Beliefs about Textbook Contents

\begin{tabular}{|c|c|c|}
\hline Subcategories & & Condensation \\
\hline Relevance of the content & - & $\begin{array}{l}\text { There are many topics about which teachers disagree such as the argument that children are } \\
\text { given so much information about sexuality that far from helping them, it arouses curiosity that } \\
\text { leads them to seek erroneous information. } \\
\text { Children are exposed to abuse. Thus, it is very important that they know about sexuality. }\end{array}$ \\
\hline Omitting content & - & $\begin{array}{l}\text { Talking about contraceptives is avoided, even though it is mentioned in the textbook. Teachers } \\
\text { believe that it is not convenient for the students to know about contraception, and the guide- } \\
\text { line has been given that the best contraception is to abstain because they are not yet ready } \\
\text { to initiate sexual relations. }\end{array}$ \\
\hline
\end{tabular}

Source: Self-made

\section{Table 4}

Category 2: Beliefs About the Characteristics of Students

\begin{tabular}{lll}
\hline Subcategories & - & Condensation \\
\hline Maturity & - & $\begin{array}{l}\text { Being able to talk about sexuality issues depends on the level of student understanding. The } \\
\text { is necessary to determine whether the girls are already menstruating. I do a survey; if a } \\
\text { respondent is not menstruating, I speak with her mother before approaching the subject. }\end{array}$ \\
\hline Discipline & - & $\begin{array}{l}\text { Being able to teach sexuality issues depends on group discipline. If the group is undisci- } \\
\text { plined, I do not teach the topic. }\end{array}$ \\
& $-\quad \begin{array}{l}\text { You must carefully choose your words and the way things are explained. You must also an- } \\
\text { alyze the children's questions properly. It is not a subject where you can talk without limits. }\end{array}$ \\
\hline
\end{tabular}

Source: Self-made

\section{Table 5}

Category 3: Beliefs About Teacher Training

\begin{tabular}{lll}
\hline Subcategories & - & We are asked to teach subjects about which we are not prepared. \\
\hline Need for teacher training & - & $\begin{array}{l}\text { In the Normal School, we should be taught how to plan and what strategies to use for } \\
\text { sex education. }\end{array}$ \\
& - & $\begin{array}{l}\text { It would be good to update the curriculum because courses always focus on reading, } \\
\text { Spanish, and mathematios, but not on sexuality. }\end{array}$ \\
Indifference toward training & - & There is ignorance as to how to approach sex education, or it is simply avoided. \\
\hline
\end{tabular}

Source: Self-made 
"How is it possible that when they are 14 or will be 15 years old instead of having a party, they have a baby in their arms?" And then that's where I tell them that there are things to avoid, pregnancy, and that the least they must do is have sex (Elena).

As we can see, the teacher knows how pregnancy affects girls' lives by acquiring responsibilities for which neither they nor their parents are prepared; likewise, the speech denotes how the biological aspects of sexuality are more critical than the affective, relational, and sociocultural issues. In this sense, Da Silva (2012) and Rangel (2018) also reaffirm that sexual education in elementary and secondary schools in Mexico is marked by a biomedical discourse characterized by an emphasis on diseases, pregnancies, hygienic care, and biological changes in adolescence.

Another important finding is the lack of sexual education among the teachers themselves. For example, the following teacher talks about how they are asked to teach subjects on which they have not received adequate instruction:

They ask us about these issues, but they don't instruct us or tell us how. In other words, we must read and see how we explain things to kids, and we are not prepared. It should start when future teachers study at the Normal School. Those who will become teachers should take a course that will guide them on how to plan, how to do it, and what strategies to use. Sometimes I feel nervous, precisely because I don't know if a group will have doubts and I will not know how to explain things to them or I will not know everything about the subject (Laura).

Da Silva (2012) has pointed out that teachers feel devoid of the knowledge and tools to address sexual education, leaving little space for them to find an answer to the questions that concern students.

Several teachers accepted that they need to receive training to be able to teach sex education. "Yes, it would be good to update because we always focus on reading, Spanish, mathematics ... But not on sexuality" (Karla). "Either there is ignorance on how to approach it, or it is simply avoided. I mean, two things happen here, but there must be sexual education in our professional training" (Veronica). This information is consistent with a study by Rosales and Salinas (2017), in which all participants agreed that they lack training in sex education. Iyer and Aggleton (2013) found that teachers revealed their lack of knowledge about sexual reproductive health issues and concluded that attitudes, beliefs, and superstitions related to young people's sexual activity inevitably affect the content and nature of sexuality education provided in school. In addition, a report made between 2016 and 2017 by the German Federal Centre for Health Education and the European Network of the International Planned Parenthood Federation presents a new assessment of sex education in Western Europe, Eastern Europe, and Central Asia. Although in 21 of the 25 countries, there is currently a law, policy, or strategy either requiring or supporting sexuality education curricula in formal school settings, in practice, only in three of the 25 countries were most teachers sufficiently trained to teach sex education (Ketting \& Ivanova, 2018). Most teachers had not been trained in the remaining countries or had participated in only a short (one day) course.

According to Fazio et al. (2020), in Italy, elementary school teachers generally have low science teaching efficacy beliefs. Their poor science background is mainly shaped by years of traditional, teachercentered didactic activities, where science teaching is based on the transmission of general concepts to students. However, they showed that after attending an inquiry-based workshop and organizing a science fair, teachers highlight a positive evolution of their science teaching efficacy beliefs and more faith in young pupils' capabilities to approach science subjects.

\section{Conclusions}

We consider it necessary to work with elementary school teachers on transforming their beliefs about teaching sex education. If they keep omitting this subject in schools, then they will contribute to the maintenance of risky sexual practices, unwanted pregnancies in girls and adolescents, and high rates of contagion of sexually transmitted diseases.

Also, it is crucial to address sexuality as an element of interpersonal relationships since sex education must improve people's quality of life and well-being. This must integrate aspects such as love, respect, inclusion, gender equality, responsibility, and commitment, just to name a few. It must go beyond what has traditionally been a starting point: the biomedical approach.

Regarding the conditions in which elementary school educators teach sexuality issues, we suggest stopping taking girls' sexual maturity as a reference point. We must remember that the development of sexual characteristics is a process that occurs differently in each human being, so it is not feasible to continue taking it as a criterion for deciding whether to explain a topic.

Another essential aspect is teacher training. We must be aware of how necessary it is to modify teaching practices. They are not sufficient to respond to current global demands. The lack of knowledge and didactic tools for handling content such as sexuality leads many teachers to choose to avoid the subject or approach it superficially. As it does not appear in their 
professional training curriculum, they omit the issue even though the subject is indicated in elementary school programs when working with students.

In conclusion, we can say that at the primary level, teachers play a representative role with their students since, in some cases, they may be the only people from whom children learn about sexuality. Therefore, we think that proper sex education in elementary school would allow children to have accurate information to know more about their bodily functions and improve coexistence through respect for others' rights and through developing the skills, attitudes, and values to enjoy their sexuality.

\section{References}

Da Silva, D. (2012). La producción de lo normal y lo anormal: Un estudio sobre creencias de género y sexualidad entre docentes de escuelas municipales de Novo Hamburgo, Brasil [The production of normal and abnormal: A study on gender and sexuality beliefs among teachers of municipal schools in Novo Hamburgo, Brazil]. Revista Subjetividad y Procesos Cognitivos, 16(1), 178-199.

Denzin, N. (1979). The research act in sociology. Aldine.

Díez, A. (2016). Más sobre la interpretación (II). Ideas y creencias [More about interpretation (II). Ideas and beliefs]. Revista de la Asociación Española de Neuropsiquiatría, 37(131), 127-143. http://scielo. isciii.es/scielo.php?script=sci_arttext\&pid=S0211$57352017000100008 \& \operatorname{lng}=$ es\&tIng=es

Fazio, C., Di Paola, B., \& Battaglia, O. R. (2020). A study on science teaching efficacy beliefs during pre-service elementary training. International Electronic Journal of Elementary Education, 13(1), 89-105. https://www.iejee.com/index. php/IEJEE/article/view/1138

Fishbein, M., \& Ajzen, I. (1975). Belief, attitude, intention and behavior: An introduction to theory and research. Adison-Wesley.

Gimeno, J. (2010). ¿Qué significa el currículum? (Adelanto) [What does the curriculum mean? (Advancement)]. Sinéctica, (34), 11-43. http:// www.scielo.org. $\mathrm{mx} /$ scielo.php?script=sci_ arttext\&pid=\$1665-109 $\times 2010000100009 \& \operatorname{lng}=e^{-}$ \&thng=es
Grupo Interistitucional para la Prevención del Embarazo en Adolescentes. (2018). Estrategia nacional para la prevención del embarazo en adolescentes [National strategy for the prevention of adolescent pregnancy]. (Executive report ENAPEA 2018). https://www. gob.mx/cms/uploads/attachment/file/417443/ Informe_Ejecutivo_GIPEA_2018.pdf.

Hudelson, P. M. (1994). Qualitative research for health programmes. Division of mental health. World Health Organization.

Instituto Nacional de Estadística, Geografía e Informática. (2020). Censo de población y vivienda 2020 [Population and Housing Census 2020]. http://cuentame.inegi.org.mx/ poblacion/escolaridad.aspx?tema=B

Instituto Nacional de Estadística, Geografía e Informática. (2020/may/13th). Estadísticas a propósito del día del maestro [Press release]. https://www.inegi.org.mx/contenidos/ saladeprensa/aproposito/2020/EAP_ Maestro2020.pdf

Instituto Nacional de las Mujeres. (2018). Estrategia nacional para la prevención del embarazo en adolescentes [National strategy for the prevention of adolescent pregnancy]. https:// www.gob.mx/cms/uploads/attachment/ file/425939/Informe_Ejecutivo_GIPEA_2018.pdf

Iyer, P., \& Aggleton, P. (2013). Sex education should be taught, fine... but we make sure they control themselves: teachers' beliefs and attitudes towards young people's sexual and reproductive health in a Ugandan secondary school. Sex Education, 13(1), 40-53.

Ketting, E., \& Ivanova, O. (2018). Sexuality education in Europe and Central Asia. State of the art and recent developments. BZgA: Federal Center for Health Education. https://www.ippfen.org/ sites/ippfen/files/2018-05/Comprehensive\%20 Country\%20Report\%200n\%20CSE\%20in\%20 Europe\%20and\%20Central\%20Asia_0.pdf

Kvale, S. (2008). Las entrevistas en investigación cualitativa [Qualitative Research Interviews]. Morata.

Le Compte, M. D. \& Goetz, J. P. (1982). Problems of reliability and validity of ethnographic research. Review of Educational Research, 52(1), 31-60. 
Mar, P. (2009). El cuerpo como sí mismo [The body as itself]. En: N. Durán, \& M. Jiménez (Eds.), Cuerpo, sujeto e identidad (pp. 139-167). Universidad Nacional Autónoma de México/Plaza y Valdés Editores.

Marseille, E., Mirzazadeh, A., Biggs, M. A., Miller, A. P., Horvath, H., Lightfoot, M., Kahn, J. G. (2018). Effectiveness of school-based teen pregnancy prevention programs in the USA: A systematic review and meta-analysis. Prevention Science, $19,468-489$

Meneses, E. (1999). Las enseñanzas de la historia de la educación en México [The teachings of the history of education in Mexico]. Universidad Iberoamericana.

Mirzazadeh, A., Biggs, M. A., Viitanen, A., Horvath, $H_{\text {., }}$ Wang, L. Y., Dunville, R., Marseille, E. (2018). Do school-based programs prevent HIV and other sexually transmitted infections in adolescents? A systematic review and meta-analysis. Prevention Science, 19, 490-506.

Navarrete, Z. (2015). Formación de profesores en las escuelas normales de México [Teacher training in normal schools in Mexico]. Siglo XX. Revista Historia dela Educación Latinoamericana, 17(25). 17-34. https://doi.org/10.19053/01227238.3805

Organización para la Cooperación y el Desarrollo Económico. (2018). La OCDE sostiene que es necesario redoblar los esfuerzos para mejorar la equidad en la educación [The OECD states that it is necessary to redouble efforts to improve equity in education]. http://www.oecd. org/centrodemexico/medios/laocdesostien equeesnecesarioredoblarlosesfue rzosparamejorarlaequidadenlaeducacion.htm

Ortega y Gasset, J. (2000). Ideas y creencias y otros ensayos [Ideas and beliefs and other essays]. Alianza Editorial.

Palencia, M., \& González, R. (2015). Libros escolares y políticas públicas de género: Un estudio retrospectivo [School books and public gender policies: A retrospective study]. Temas de educación, 21(1), 31-46.

Preston, M. (2013). Very very risky: Sexuality education teachers' definition of sexuality and teaching and learning responsibilities. American Journal of Sexuality Education, 8, 18-35.
Ramírez, J. (2013). "Traer cortita a la mujer": Una creencia sobre las relaciones de género en jóvenes de Guadalajara [Keep an eye on the woman. A belief about gender relations in young people from Guadalajara]. Relaciones. Estudios de historia y sociedad, 34(133), 15-40. http:// www.scielo.org.mx/scielo.php?script=sci_ arttext\&pid=S0185-39292013000100002\&lng=es\& tlng=es

Ramírez, J., López, G., \& Padilla, F. (2009). ¿Nuevas generaciones, nuevas creencias? Violencia de género y jóvenes [New generations, new beliefs? Gender violence and youth]. La ventana. Revista de estudios de género, 3(29), 110-145. http://www.scielo.org.mx/ scielo.php?script=sci_arttext\&pid=\$140594362009000100006\&lng=es\&t|ng=es

Rangel, L. (2018). Producción de discursos sobre sexualidad en la escuela y heteronormatividad: El caso de un profesor de Biología [Production of discourses on sexuality at school and heteronormativity: The case of a Biology teacher]. Revista de El Colegio de San Luis, 8(15), 269-290.

Rosales, A., \& Salinas, F. (2017). Educación sexual y género en primarias mexicanas ¿Qué dicen los libros de texto y el profesorado? [Sex education and gender in Mexican elementary schools What do the textbooks and teachers say?] Revista Electrónica Educare, 21(2), 1-21.

Sánchez, M., \& Montoya, Y. (July/August 2019). Panorama del embarazo y mortalidad materna adolescente en México [Outlook of adolescent pregnancy and maternal mortality in Mexico]. Boletín CONAMED, 25(5), 53-64. http://www. conamed.gob.mx/gobmx/boletin/pdf/ boletin25/numero_completo.pdf

Secretaría de Educación Pública. (2017). Aprendizajes clave para la educación integral [Key learnings for comprehensive education]. https://www. planyprogramasdestudio.sep.gob. $\mathrm{mx} /$ indexdescargas.html

Wood, T. D. (2012). Teacher perceptions of genderbased differences among elementary school teachers. International Electronic Journal of Elementary Education, 4(2), 317-345. https:// WWw.iejee.com/index.php/IEJEE/article/ view/202 
World Health Organization. (2006). Defining sexual health: Report of a technical consultation on sexual health, 28-31 January 2002, Geneva. https://www.who.int/reproductivehealth/ publications/sexual_health/defining_sexual_ health.pdf?ua=1 